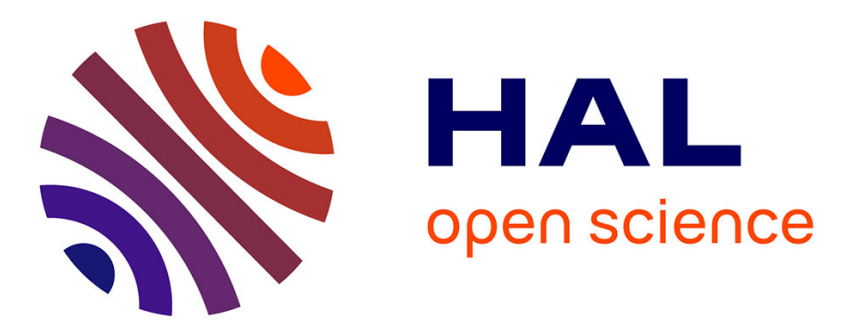

\title{
Desirable properties of wood for sustainable development in the twenty-first century
}

Kenneth E. Skog, Theodore H. Wegner, E. M. (ted) Bilek, Charles H. Michler

\section{To cite this version:}

Kenneth E. Skog, Theodore H. Wegner, E. M. (ted) Bilek, Charles H. Michler. Desirable properties of wood for sustainable development in the twenty-first century. Annals of Forest Science, 2015, 72 (6), pp.671-678. 10.1007/s13595-014-0406-0 . hal-01284201

\section{HAL Id: hal-01284201 https://hal.science/hal-01284201}

Submitted on 7 Mar 2016

HAL is a multi-disciplinary open access archive for the deposit and dissemination of scientific research documents, whether they are published or not. The documents may come from teaching and research institutions in France or abroad, or from public or private research centers.
L'archive ouverte pluridisciplinaire HAL, est destinée au dépôt et à la diffusion de documents scientifiques de niveau recherche, publiés ou non, émanant des établissements d'enseignement et de recherche français ou étrangers, des laboratoires publics ou privés. 


\title{
Desirable properties of wood for sustainable development in the twenty-first century
}

\author{
Kenneth E. Skog • Theodore H. Wegner • E. M. (Ted) Bilek • \\ Charles H. Michler
}

Received: 11 April 2014 / Accepted: 1 July 2014 / Published online: 23 July 2014

(C) INRA and Springer-Verlag France 2014

\section{Introduction}

We previously identified desirable properties for wood based on current market-based trends for commercial uses (Wegner et al. 2010). World business models increasingly incorporate the concept of social responsibility and the tenets of sustainable development. Sustainable development is needed to support an estimated 9 billion people by 2050 within the carrying capacities of the Earth. The supply of raw materials for the array of products we know today will be insufficient, and we will need to sustainably use forest-based resources as major sources of materials. For example, increasing demand for higher quality food will require enhanced packaging performance to minimize loss in shipping. Also, housing and commercial building construction will need to be affordable, energy-efficient, durable, easily maintained, and natural-

\section{Handling Editor: Jean-Michel Leban}

Contribution of the co-authors Wegner suggested using the Vision 2020 report as the basis for determining how sustainability requirements will likely influence desirable properties. Skog wrote the article with text provided by Wegner clarifying sustainability requirements and nanocellulose contributions and requirements. Bilek provided a review of markets for nanocellulose-based products. Michler provided a review on biotechnology as a tool for manipulating properties.

Key message Meeting human needs within the Earth's carrying capacity will require responsible sustainable development. Enhanced properties in generalist trees and potentially in specialist trees can help to efficiently meet people's expanding needs for materials and products while storing carbon, reducing GHGs, and reducing nonrenewable materials use.

K. E. Skog $(\varangle) \cdot$ T. H. Wegner • E. M. Bilek

USDA Forest Service Forest Products Laboratory, Madison,

WI 53726, USA

e-mail: kskog@fs.fed.us

C. H. Michler

USDA Forest Service, Northern Research Station, West Lafayette,

IN 47907, USA disaster resistant. In addition, growing concerns about climate change are increasing interest in wood-based materials because of their low-carbon emission in production and ability to sequester carbon and allow forest carbon stocks to increase. In response to these socio-economic and environmental imperatives, the World Business Council for Sustainable Development (WBSCD) prepared a Vision 2050 report on changes required to attain sustainability goals (WBCSD 2010). They identify features of a sustainable world, how those features could be realized, and the role of business in enabling rapid progress toward sustainability. In this paper, we review highlevel goals from the WBSCD report and suggest goals for six of their nine pathway elements to a sustainable future that are particularly important in determining desirable properties of wood in the twenty-first century. We believe their report is a valuable basis for assessing wood needs because it provides an integrated vision across social, environmental, and economic sectors and provides views from industries that will implement many needed changes. Figures on projected needed changes are from their report. Our objective is to evaluate how a broad and long-range set of needs for sustainable development will influence commercial requirements for wood and desirable wood properties. We emphasize ways forest products and wood properties can contribute to greenhouse gas (GHG) mitigation and provide a vision for sustainable production and use.

\section{Responsible sustainable development}

A goal for responsible sustainable development is to modify use of world resources from a business-as-usual path, which would increase resource use to 2.3 times the Earth's capacity by 2050 . We currently use resources at a rate 1.5 times the Earth's capacity. We must decrease resource use to equal to Earth's capacity while providing food, water, shelter, energy, 
education, healthcare, mobility, and consumer goods for $30 \%$ more people by 2050 . In addition, sustainable development goals must be attained while mitigating impacts of climate change and increasing urbanization.

The business-as-usual scenario includes increasing human needs, inertia in governance, and continuing environmental degradation. Population is projected to increase from 6.9 to 9 billion people, with $98 \%$ of growth in developing countries and urban populations doubling. Most economic growth will be in developing and emerging economies with a growing middle class. This growing middle class will consume more resources per capita to provide better housing, education, healthcare, and lifestyle amenities.

Attaining a sustainable future will require radical changes in nine elements of a pathway to a sustainable future (Table 1). The Vision 2050 report summarizes requirements that include (1) people's values and behaviors; (2) human development: enabling education and economic empowerment, particularly of women, and developing radically more eco-efficient lifestyles and behaviors; (3) economy: incorporating the cost of externalities including carbon storage, water, and other ecosystem services; (4) agriculture: doubling agricultural output without increasing land or water use; (5) forests: halting deforestation and increasing yields from planted forests; (6) energy and power: halving carbon emissions worldwide from 2005 levels through a shift to low-carbon energy systems, and highly efficient demand systems including buildings; (7) buildings: moving toward zero net energy use; (8) mobility: providing universal access to low-carbon transportation; and (9) materials: providing a 4- to 10-fold efficiency improvement in use of resources and materials. We judge that the greatest impact on requirements for wood and desirable properties for wood will come from changes in the economy, forests, energy and power, buildings, mobility, and materials.

Goals for the economy, energy and power, mobility, and forests will be driven in part by the need to reduce GHG emissions. Findings of the Intergovernmental Panel on Climate Change (IPCC) show that net GHG emissions must be reduced radically. Net emissions can be reduced by carbon sequestration in forests and long-lived wood products and use of alternative fuels. A $66 \%$ chance of keeping Earth's planetary warming below an internationally agreed $2{ }^{\circ} \mathrm{C}$ above preindustrial levels requires that no more than one trillion metric tons of carbon be released to the atmosphere (IPCC 2013, p 25). Just over half this level has been emitted. At the rate emissions are growing, the one trillionth ton will be released around 2040.

Vision 2050 suggests an $80 \%$ reduction in GHG emissions per annum over the business-as-usual projection by 2030 . To attain this requires a global price on carbon emissions. With resulting higher cost for fossil fuel use, alternatives would be more economical, including use of wood for products and energy to reduce carbon emissions. Investments in demand- side efficiency could provide $50 \%$ of emission savings. Remaining savings would be met $50 \%$ by using renewable fuels (including wood) and $50 \%$ by nuclear power and by fossil fuels using carbon capture and storage. Wood use can contribute to increasing demand-side efficiency in production of products by substitution for materials that have more emissions in manufacturing and increasing production of woodbased renewable fuels.

Goals for forest-based materials use will be driven by the need to reduce use of nonrenewable resources radically. Nonrenewable material use must be reduced from $85 \mathrm{t}$ per person per year in 2009 to $5 \mathrm{t}$ per person per year. This will require closed-loop recycling and reduction in use of material per unit of end use (i.e., dematerialization). Wood materials can contribute by increasing recycling and by innovative use of cellulose nanomaterials in a range of material applications to increase strength and stiffness per unit weight and other functions.

Forests and forest products can provide major contributions to GHG reduction and dematerialization goals. Contributions include an increase in wood use for shelter, renewable fuel, and consumer goods largely from a threefold increase in plantation yield and harvest, which would cover $60 \%$ more area, and by a $50 \%$ overall increase in roundwood harvest by 2030. Additional volume could also come from modified natural forest managed at a lower intensity that would also help store carbon. The Vision 2050 report suggests that by 2050, limited additional harvest would come from modified natural forests and no harvest from primary (i.e., old growth) forests. Carbon incentives would result in reduced deforestation, an overall $10 \%$ increase in forest area, and an increase in forest carbon to offset GHG emissions. Wood's role in building construction will increase because it can store carbon long term and offset emissions by substituting for more energyintensive materials. Green building initiatives and innovative uses (such as cross-laminated timber construction) will expand wood use beyond traditional regions and building styles. Wood use for energy, particularly wood residue use, can contribute to reducing GHG emission by producing electric power and gas or liquid transportation fuels. Wood can contribute toward the needed $90 \%+$ reduction in nonrenewable materials use by increased use of wood in buildings, increased recycling of wood and paper, and innovations in use of nanocellulose.

The degree to which wood use is increased in building construction, electric power, heating, and nanomaterials applications will depend on (1) the technical performance of wood in end uses (e.g., housing), GHG reduction objectives, and nonrenewable material reduction objectives (e.g., recyclability, increased strength per unit weight); (2) incentives to recognize the GHG and nonrenewable material reduction performance of wood (e.g., green building standards); and (3) cost of wood materials and manufacturing compared with 


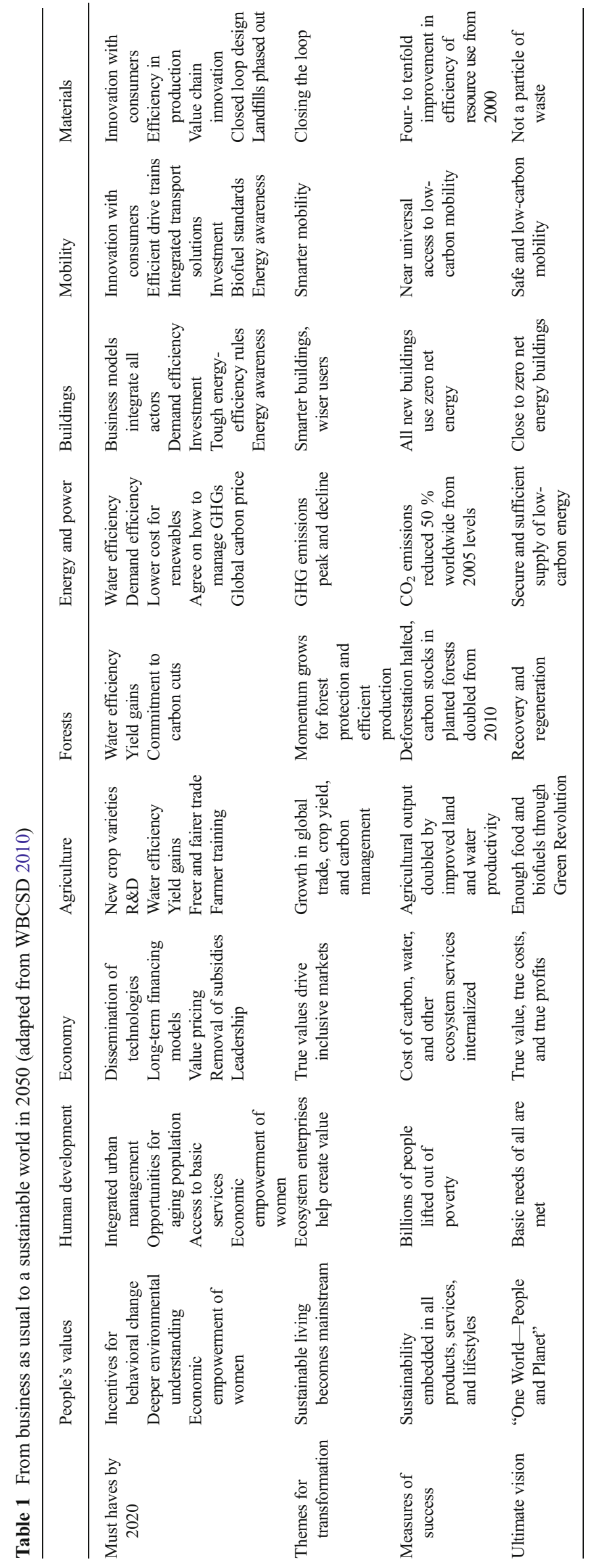


alternative materials. Costs will be influenced by economic or policy incentives (e.g., forest taxation, carbon price or tax, or renewable fuel standards).

\section{Forest products contributing to sustainability}

Forests and forest products can substantially contribute toward sustainability goals; reducing GHG emissions; and reducing nonrenewable materials needs via substitution, recycling, and dematerialization. First, enhanced conventional wood will be needed for construction and shelter in the form of sawn wood, panels, and furniture parts, and for communications, sanitation, and shipping in the form of paper and paperboard. Second, wood will be needed for efficient thermochemical conversion processes to produce heat, gas, or liquid fuels for transportation, electric power, and chemicals. Third, wood will be needed for efficient use in biochemical conversion processes to produce liquid fuels for transportation and chemicals. Fourth, wood will be need for efficient production of nanocellulosic materials (nanofibrils and nanocrystals) that can be used to provide more strength and stiffness per unit material and replace nonrenewable materials in a range of applications. For wood products to provide these contributions while maintaining forest health and forest carbon inventory will require increased productivity of forest plantations through increased plantation area and growth rates.

The following sections note the wood properties needed for the four wood use categories - conventional, thermal conversion, biochemical conversion, and cellulose nanomaterials. We also discuss (1) how conventional wood uses are likely to provide more GHG emission reduction than uses of wood for energy and (2) a vision for the contribution of cellulosic nanomaterials to meeting sustainable material needs.

\section{Wood properties needed}

Conventional solid-sawn, panel and nonpanel composites, and paper and paperboard products can provide higher value per unit with certain enhancements to wood properties: for lumber and panels, more uniformity across trees, improved stem form, less juvenile wood, sufficiently high density for good strength and stiffness, lower microfibril angle in the S2 layer of wood cell walls, and-for appearance grades of lumber and plywood - more desirable color; for paper and paperboard, higher cellulose content relative to lignin and hemicellulose, in gymnosperm species (softwoods) easier to remove lignin, and in angiosperm species (hardwoods) longer and more flexible tracheids.

Thermal conversion processes can use both wood and bark. Wood properties that yield higher value per unit input are relatively straightforward. Increasing throughput for thermal processes requires high-energy density of wood. High lignin content is also desirable because of its higher energy density.

Biochemical conversion in the forest biorefinery concept has a different set of wood property needs and can be product specific. Bark does not contain sugars and is difficult to process; for producing sugars for ethanol or higher-value chemicals, bark often represents a yield loss and transportation dead-load. However, bark contains a different cocktail of chemicals and may provide valuable by-products. Conversion of wood to sugars for fermentation-based products requires separating constituent wood polymers. Trees with lower lignin content would provide value in higher sugar yields, but decreased lignin content may not significantly increase biochemical conversion rates. Hemicellulose sugars are more difficult to convert to some chemical products (for example, fermentation to ethanol) and easier to convert to other products (such as furan-2,5-dicarboxylic acid useful in producing polyester), so hemicellulose can represent either a yield loss or a desired intermediate. Tree species with elevated xylan production would be of value for biorefineries capitalizing on fivecarbon sugars. Interest is increasing in developing coprocesses to produce higher-value chemicals from fivecarbon sugars and co-products from lignin. What tree characteristics will most benefit biorefineries is difficult to predict, but there is intense interest in characterizing species and species variability and manipulating lignin, cellulose, and hemicellulose content and secondary characteristics to improve rates, yields, and product mixes.

Cellulosic nanofibrils about $10 \mathrm{~nm}$ in diameter and up to about $600 \mathrm{~nm}$ in length are composed of cellulose polymer chains. These nanofibrils combine to make microfibrils, which make up wood cell walls. Portions of the cellulose chains form into ordered regions, referred to as crystals. Crystalline cellulose has strength along its axis per unit weight that is greater than $\operatorname{Kevlar}{ }^{\circledR}$ and generally has properties similar to other high-performance materials used for reinforcement of composites (Moon et al. 2011). Addition of cellulosic nanomaterials as a reinforcement phase in weaker polymers can reduce consumption of nonrenewable materials. The benefit of nanocrystals in reinforcing composite material would be enhanced by increasing their length-to-diameter ratio (aspect ratio) beyond the current range of 10 to 30 . The strength of wood-plastic composites is greater when higher aspect ratio wood fibers are used (Stark and Rowlands 2003; Schirp and Stender 2010). Cellulosic nanofibrils contain a mixture of crystalline and amorphous regions with a net strength dictated by the weaker amorphous portions. They are still incredibly strong, and with aspect ratios $\geq 60$ are more easily utilized as a reinforcing phase in composites. Cellulose nanomaterials also have reactive surfaces; chemically modifying these surfaces help bond other chemicals that facilitate self-assembly or controlled dispersion in a range of matrix polymers and maximize both particle-particle and particle- 
matrix bond strengths. Existing cellulosic nanomaterial composites include those that are transparent, have tensile strengths greater than cast magnesium, and have low coefficient of thermal expansion (Moon et al. 2011).

\section{Wood properties contributing to storing carbon and providing GHG offsets}

Several uses and desirable properties of wood mitigate GHG accumulation in the atmosphere-a key sustainability goal. We need systems of forests and forest products that maintain and even increase carbon inventory in forests. Economical industrial timber utilization is vital to sustaining forests and avoiding large-scale deforestation by making forestry more economical and sustainable (Ince 2010). A key need in retaining forests and forest carbon is to provide low-cost wood, conversion technologies, and end-use applications that are cost and performance competitive with nonrenewable materials. High-productivity forest plantations can contribute by providing low-cost wood materials with desired properties. Low-cost wood can also come from medium productivitymodified natural forests. Trees that are resistant to insects, disease, and fire and tolerant of variable climate, including greater ranges of temperature and precipitation, are needed for high-productivity and low-cost wood and carbon sequestration.

The contribution of wood products to storing carbon and offsetting emissions by substitution for more energy-intensive materials can be increased by use of advanced technologies such as cross-laminated timber (CLT) in constructing more multistory nonresidential and apartment buildings. In 2011, in the USA, 10,500 new low-rise nonresidential buildings (six stories or less) or major additions to such buildings totaled 68 million square meters of floor space. About $12 \%$ of this construction used wood framing. Under current building codes, assuming full recovery from the recent recession, increased wood framing could result in almost doubling wood use in low-rise nonresidential buildings even without the use of CLT technology (Adair et al. 2013). With use of CLT panels, many more higher-story buildings could be built using wood. CLT panels can use lumber of two qualities: (1) high strength and stiffness for laminations in the major strength direction and (2) lower strength for laminations in the minor strength direction (Yeh et al. 2012; CEN 2014). This means that only a portion of wood from forests for CLT panels needs to be high in strength and stiffness. Enhancing strength for a portion of wood production would allow an exponential increase in production of CLT panels.

Use of wood in housing and nonresidential structures also provides GHG mitigation by storing carbon for decades. The default world half-life for sawnwood in end uses, including housing and shorter life uses, is 30 years (IPCC 2006). For the
USA, the estimated half-life for single-family housing is as much as 80 years (Skog 2008). This carbon storage benefit is extended if sawnwood from buildings is recycled for use in new buildings. The extent of the reuse benefit (versus sending wood to solid waste disposal sites) is influenced by rates of forest growth with and without harvest (Bergman et al. 2013). If sawnwood and wood panel use is increased in buildings, then steel and concrete use will decrease and the net reduction in emissions will be about $2 \mathrm{t}$ carbon per tonne of carbon in wood products (Sathre and O'Connor 2010).

The GHG mitigation benefit of using wood for long-lived products and uses is generally greater than use of wood for energy (Lippke et al. 2012; Cherubini et al. 2012). A carbon mitigation benefit is still obtained from using types of wood that cannot be used in a long-lived use (or shorter-lived uses such as paper and paperboard). Such wood includes logging residue, mill residue only suitable for fuel, and biomass harvested from forests to improve forest health but is not suitable for solid-wood or paper products. The greater GHG mitigation effect for long-lived products supports the need for wood and wood properties that enhance the competitiveness of wood for solid-wood and long-lived uses such as building construction.

GHG emissions can be reduced by reducing energy use and carbon emissions associated with pulp, paper, and paperboard production. Wood properties that could help lower energy use include lower lignin content and higher ratio of syringyl to guaiacyl lignin. GHG emissions may also be reduced by incorporating nanocellulosic materials in a range of products. This can reduce material needs and GHG emissions per unit of end use.

\section{A vision for material production and use: the contributions of solid-wood products and cellulose nanomaterials}

Meeting end-use needs with low nonrenewable material use, low cost, low GHG emissions, and other low environmental impacts will require life cycle analysis to identify production and use systems that provide functions at lowest cost and with lowest environmental burdens. Key strategies will include closed-loop recycling for all materials production and use, and dematerialization of products (WBCSD 2010). Recycling of solid-wood products can be increased with use of lumber and panels that maintain strength over time and use of construction systems that are designed to facilitate recovery and reuse in new long-lived structures (Chini and Schultmann 2002).

Cellulosic nanomaterials can be used in a range of applications that contribute to material sustainability goals. They are made from renewable feedstock. They generate low-carbon emissions in transport and production relative to other materials. Their use can decouple the usual linkage where high 
stiffness and strength require high density of material. This decoupling can contribute to materials with higher strength and stiffness per unit weight. With advances in engineering, structural materials built from uniform components can be progressively dematerialized while maintaining strength and stiffness by using organized architectures: first by using random spaces, next by using uniformly ordered spaces, and finally by using optimally ordered cell size and shape, node topology, connector shape, and materials used (Schaedler et al. 2013). Cellulosic nanomaterials have strength and stiffness per unit weight that exceed many metals (Fig. 1) (Moon et al. 2011) and could contribute to dematerialization.

Cellulosic nanomaterial could contribute to displacing nonrenewable materials and to dematerialization in both largevolume markets and small-volume, higher-value markets. Several applications could each use millions of tons of cellulosic nanomaterials. Paper, paperboard, and packaging production could use cellulosic nanomaterials in the form of fillers and coatings that would decrease pulp use and increase sheet smoothness, while increasing strength and printing properties. The natural absorbency of cellulosic nanomaterials suggests their use in absorbent products, which could be made lighter and thinner. Concrete used in higher strength applications could use additions of cellulosic nanomaterials that would increase strength or decrease nonrenewable material use while maintaining strength. The addition of $0.5 \%$ by weight of cellulosic nanofibrils to cement increases concrete's fracture toughness by $20 \%$ (Stephenson 2011). Automobile exterior and interior panels could use cellulose nanomaterials to decrease car weight, potentially by over $300 \mathrm{~kg}$ (Shatkin

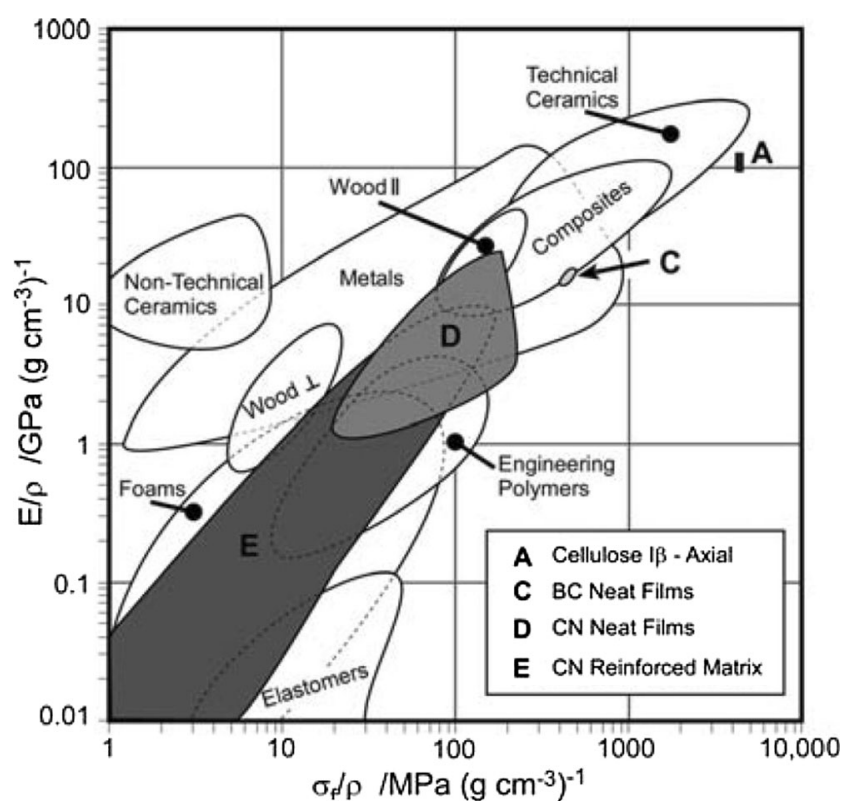

Fig. 1 Ashby plot of specific modulus $(E / \rho)$ [stiffness] versus specific strength $\left(\sigma_{f} f \rho\right)$. Regions of crystalline cellulose $(A)$, neat films $(C, D)$, and reinforced matrix composites $(E)$ are shown. (from Moon et al. 2011 as amended from Ashby 1999) et al. 2014). Cellulose nanomaterials could replace nonrenewable materials in many low-volume, higher-value uses, including structural and interior components of aircraft; filtration systems and sensors that use the ability of cellulose nanomaterials to carry functional chemicals on their surface; and construction products such as gypsum wallboard facings, insulating aerogel foams, and paints. Specialty markets for cellulose nanomaterials could include flexible printed electronics and LED video screens, medical applications including drug delivery and bone and tissue scaffolding, and 3D printing (i.e., additive manufacturing) (Shatkin et al. 2014).

Desirable wood properties for production of cellulose nanomaterials include higher crystalline (versus amorphous) cellulose in fibrils, higher crystal aspect ratio, and higher number of reactive sites to facilitate bonding to matrix material in composites and surface chemistry modification.

The modification of a tree's wood properties and subsequent patterns of tree planting and propagation will need to consider maintaining biodiversity within and between species, presumably to various degrees, in various types of forests. The Vision 2050 report suggests emphasis in meeting increased wood needs largely by increased growth on plantations with limited increases from modified natural forests and little to no harvest from primary forests.

\section{A timeline for wood property needs}

Certain wood properties are needed now for current solidwood products, pulp and paper, and combustion to produce heat. Needed properties for sawnwood, plywood, and composite panels include sufficient specific gravity, improved tree stem form, lower microfibril angle in the S2 wood cell wall layer, less juvenile wood, longer more flexible tracheids, durability in strength, resistance to decay, and for appearance grades of lumber and veneer, improved color. Properties needed now for pulp production include higher cellulose content and lower or modified lignin. Properties needed for combustion for heat include lower ash content, higher lignin, and lower moisture. Investment in modifying these properties could be economically justified in the short run by resultant lower costs and higher value, and would be justified by incentives that recognize contributions to GHG mitigation and materials recycling.

In the near future, wood properties may be needed that would lower costs for using wood in biochemical conversion technologies to produce biofuels, chemicals, and pharmaceuticals. Needed properties would include lower recalcitrant (crystalline) cellulose and higher six-carbon sugars in hemicellulose. As these technologies become commercialized, investments in modifying these wood properties could be justified by lowering costs of production for valuable products. 
Beyond the next decade, larger markets for cellulose nanomaterials may develop. As those markets are established, investments may be economically justified to lower costs or increase value by modifying wood to provide higher crystalline cellulose, higher crystal length relative to diameter, and a high number of reactive sites.

Current production of solid-wood and paper products and the sustainability benefits they provide justify a current focus on developing needed wood properties in "enhanced generalist trees"- those that perform well in providing lumber, panel, and paper uses that contribute to sustainability goals, including GHG mitigation and materials recycling. Investing in "specialist trees" that produce wood with enhanced end-use specific properties would be economically justified only if an established commercial market drives the need.

\section{Biotechnology as a tool for manipulating desirable properties}

Biotechnology is being used to modify trees to provide desirable properties; most often, the research is performed in Populus sp. (Polle et al. 2013). Compared with other forest tree species, Populus is easier to modify by transgenic technologies to improve pulping abilities or biofuel/biochemical production. In addition, increased disease (Sannigrahi et al. 2010; Polle et al. 2013) and insect resistance have also been reviewed recently (Ye et al. 2011). Families of genes in Pinus taeda L. (Gonzalez-Martinez et al. 2007) and Populus sp. (GenBank $\left.{ }^{\circledR}\right)$ are known that influence branch angle, stem thickness, lignin content, plant competition, and insect and disease resistance. It will likely be possible to manipulate trees to obtain more desirable traits, including longer more flexible tracheids (for strength in paper and composite panels), modified color of sapwood (for appearance grades of sawnwood); decreased microfibril angle (for greater strength in conifers); reduction in juvenile wood (for greater strength in conifers); greater uniformity of fiber characteristics (for pulping control); and reduction in property difference between early and latewood (decrease in color difference, increase in strength, pulping control) (Koehler and Telewski 2006; Wegner et al. 2010).

\section{Research pathways for enhancing wood contributions to sustainable development}

Modifications to forestry and forest products have the potential to contribute to radical changes needed to attain sustainable development goals. Research is needed on modifications to trees to attain faster growth and resistance to disturbance to store more carbon in forests and modifications to wood properties so that wood is competitive in meeting human needs, storing carbon, reducing GHG emissions, and reducing nonrenewable material use. Research is also needed to adapt wood processing technologies to the existing distribution of wood properties to make effective use of each type of wood material in order to attain sustainable development objectives. In the near term, enhanced generalist trees will help meet sustainability goals. In the longer term, when biochemical conversion technologies and nanocellulose applications are commercialized, investment in specialist trees may be economically justified by the substantially higher-value products they can provide.

Acknowledgments We thank the organizers of the 2013 MeMoWood Conference for the invitation to prepare this study and we thank the Institut National de la Recherche Agronomique (INRA) for the support to present results at MeMoWood, 1-4 October 2013, in Nancy, France.

\section{References}

Adair C, McKeever DB, Gaston C, Stewart M (2013) Wood and other materials used to construct nonresidential buildings in the United States 2011. APA-The Engineered Wood Association, Tacoma, $123 \mathrm{p}$

Ashby MF (1999) Materials selection in mechanical design, 3rd edn. Butterworth-Heinemann, Burlington

Bergman RD, Falk RH, Gu H, Napier TR, Meil J (2013) Life-cycle energy and GHG emissions for new and recovered softwood framing lumber and hardwood flooring considering end-of-life scenarios. Res. Pap. FPL-RP-672, USDA Forest Service, Forest Products Laboratory, Madison, WI, $35 \mathrm{p}$

CEN-European Committee for Standardization (2014) Timber structures - cross laminated timber-requirements (draft standard), DEN/TC - 124, http://standards.cen.eu/dyn/www/f?p= 204:110:0::::FSP PROJECT,FSP LANG ID:35029,25\&cs= 1575BDF2B3A63C 11 E69B68CD76F 27CF64. Accessed 2014 Feb 28

Cherubini F, Guest G, Strømman AH (2012) Application of probability distributions to the modeling of biogenic $\mathrm{CO} 2$ fluxes in life cycle assessment. GCB Bioenergy 4:784-798

Chini AR, Schultmann F (eds) (2002) Design for deconstruction and reuse. Proceedings of the CIB Task Group 39Deconstruction Meeting, 9 April 2002, Karlsruhe, Germany, CIB Publication 272, Rotterdam, Netherlands. http://cibworld. xs4all.nl/d1/publications/Pub1272/proceedings.pdf. Accessed 2014 Feb 28

Gonzalez-Martinez SC, Wheeler NC, Ersoz E, Nelson CD, Neale DB (2007) Association genetics in Pinus taeda L. I. Wood Prop Traits Genet 175:399-409

Ince, PJ (2010) Global sustainable timber supply and demand. Sustainable development in the forest products industry, Chapter 2. In: Rowell RM, Caldeira F, Rowell JK. Sustainable development in the forest products industry. Porto, Portugal: Universidade Fernando Pessoa, 2010, pp 29-41. ISBN: 9789896430528

IPCC (2006) Chapter 12 - harvested wood products. In: Eggleston HS, Buendia L, Miwa K, Ngara T, Tanabe K (eds) Volume 4 of 2006 IPCC Guidelines for National Greenhouse Gas Inventories, Prepared by the National Greenhouse Gas Inventories Programme. IGES, Japan 
IPCC (2013) Summary for policymakers. In: Stocker TF, Qin D, Plattner G-K, Tignor M, Allen SK, Boschung J, Nauels A, Xia Y, Bex V, Midgley PM (eds) Climate Change 2013: The physical science basis. Contribution of Working Group I to the Fifth Assessment Report of the Intergovernmental Panel on Climate Change. Cambridge University Press, Cambridge

Koehler L, Telewski FW (2006) Biomechanics and transgenic wood. Amer J Bot 93:1433-1438

Lippke B, Gustafson R, Venditti R, Steele P, Volk TA, Oneil E, Johnson L, Puettmann ME, Skog K (2012) Comparing life-cycle carbon and energy impacts for biofuel, wood product, and forest management. Forest Prod J 62:247-257

Moon RJ, Martini A, Nairn J, Simonsen J, Youngblood J (2011) Cellulose nanomaterials review: structure, properties and nanocomposites. Chem Soc Rev 40:3941-3994

Polle A, Janz D, Teichmann T, Lipka V (2013) Poplar genetic engineering: promoting desirable wood characteristics and pest resistance. Appl Microbiol Biotechnol 97:5669-5679

Sannigrahi P, Ragauskas AJ, Tuskan GA (2010) Poplar as a feedstock for biofuels: a review of compositional characteristics. Biofuels Bioprod Bioref 4:209-226

Sathre R, O'Connor J (2010) Meta-analysis of greenhouse gas displacement factors of wood product substitution. Environ Sci Policy 13: 104-114

Schaedler TA, Jacobsen AJ, Carter WB (2013) Toward lighter, stiffer materials. Science 341:1181-1182
Schirp A, Stender J (2010) Properties of extruded wood-plastic composites based on refiner wood fibers (TMP fibers) and hemp fibers. Eur J Wood Wood Prod 68:219-231

Shatkin J, Wegner T, Bilek EM, Cowie (2014) Market projections for cellulose nano-material enabled products-part 1: applications. Tappi J 13(5):9-16

Skog KE (2008) Sequestration of carbon in harvested wood products for the United States. Forest Prod J 58:56-72

Stark NM, Rowlands RE (2003) Effects of wood fiber characteristics on mechanical properties of wood/polypropylene composites. Wood Fiber Sci 35:167-174

Stephenson KM (2011) Characterizing the behavior and properties of nano cellulose reinforced ultra high performance concrete. Theses and dissertations, Paper 1579, University of Maine

Wegner T, Skog KE, Ince PJ, Michler CJ (2010) Uses and desirable properties of wood in the 21st century. J For 108:165-173

World Business Council for Sustainable Development (2010) Vision 2050 - a new agenda for business. Geneva, Switzerland, 74p. http://www.wbcsd.org/vision2050.aspx. Accessed 2014 Jan 2

Ye X, Busov V, Zhao N, Meilan R, McDonnell LM, Coleman HD, Mansfile SD, Chen F, Li Y, Cheng Z-M (2011) Transgenic Populus trees for forest products, bioenergy, and functional genomics. Crit Rev Plant Sci 30:415-434

Yeh B, Gagnon S, Williamson T, Pirvu C, Lum C, Kretschmann D (2012) The North American product standard for cross-laminated timber. Wood Des Focus 22:13-21 